Article

\title{
The Effect of RF Sputtering Conditions on the Physical Characteristics of Deposited GeGaN Thin Film
}

\author{
Cao Phuong Thao ${ }^{1}$, Dong-Hau Kuo ${ }^{2, *} \mathbb{C}^{\text {D }}$, Thi Tran Anh Tuan ${ }^{3, * \mathbb{D}}$, Kim Anh Tuan ${ }^{1}$, \\ Nguyen Hoang $\mathrm{Vu}^{1}$, Thach Thi Via Sa Na ${ }^{1}$, Khau Van Nhut ${ }^{1}$ and Nguyen Van Sau ${ }^{3}$ \\ 1 School of Engineering and Technology, Tra Vinh University, Tra Vinh 87000, Vietnam; \\ cpthao@tvn.edu.cn (C.P.T.); katuan@tvu.edu.cn (K.A.T.); nghvu@tvu.edu.vn (N.H.V.); \\ viasana@tvu.edu.cn (T.T.V.S.N.); nhutkhau@tvu.edu.vn (K.V.N.) \\ 2 Department of Materials Science and Engineering, National Taiwan University of Science and Technology, \\ Taipei 10607, Taiwan \\ 3 School of Basic Sciences, Tra Vinh University, Tra Vinh 87000, Vietnam; nvsau@tvu.edu.vn \\ * Correspondence: dhkuo@mail.ntust.edu.tw (D.-H.K.); thitrananhtuan@tvu.edu.vn (T.T.A.T.); \\ Tel.: +886-2-27303291 (D.-H.K.)
}

Received: 5 September 2019; Accepted: 1 October 2019; Published: 6 October 2019

\begin{abstract}
Ge}_{0.07} \mathrm{GaN}$ films were successfully made on $\mathrm{Si}(100), \mathrm{SiO}_{2} / \mathrm{Si}(100)$ substrates by a radio frequency reactive sputtering technique at various deposition conditions listed as a range of $100-400^{\circ} \mathrm{C}$ and $90-150 \mathrm{~W}$ with a single ceramic target containing 7 at \% dopant Ge. The results showed that different RF sputtering power and heating temperature conditions affected the structural, electrical and optical properties of the sputtered $\mathrm{Ge}_{0.07} \mathrm{GaN}$ films. The as-deposited $\mathrm{Ge}_{0.07} \mathrm{GaN}$ films had an structural polycrystalline. The GeGaN films had a distorted structure under different growth conditions. The deposited-150 W Ge $0.07 \mathrm{GaN}$ film exhibited the lowest photoenergy of $2.96 \mathrm{eV}$, the highest electron concentration of $5.50 \times 10^{19} \mathrm{~cm}^{-3}$, a carrier conductivity of $35.2 \mathrm{~S} \cdot \mathrm{cm}^{-1}$ and mobility of $4 \mathrm{~cm}^{2} \cdot \mathrm{V}^{-1} \cdot \mathrm{s}^{-1}$.
\end{abstract}

Keywords: Ge donor; GaN; growth condition; heating substrate temperature; RF power; reactive sputtering; thin film property

\section{Introduction}

It is known that Gallium Nitride (GaN) and its compounds have wide bandgap, high thermal conductivity [1] and wurtzite crystal structure. They have been employed for electronics and photo-electronic components, listed as MOSFET and HJ-FET transistors, diodes and light emitting diodes (LED) [2-6].

By using the doping technique to make n-type semiconductor materials, Shuji et al. studied the efficiency between Ge and Si doping. The doping of Si had higher efficiency as the $\mathrm{GeH}_{4}$ and $\mathrm{SiH}_{4}$ precursors were applied for Ge- and Si-doped $\mathrm{GaN}$ with high electron concentrations at $2 \times$ $10^{19}$ and $1 \times 10^{19} \mathrm{~cm}^{-3}$, respectively [7]. Ge performed as a charge carrier in GaN film made by a plasma-assisted molecular beam epitaxy (MBE) system [8,9]. Many researchers have applied various deposition techniques to make Ge-doped GaN, such as hydride-vapor phase-epitaxy (HVPE) [10], chemical-vapor-deposition (MOCVD) [7,11,12], metalorganic -vapor- phase-epitaxy (MOVPE) [13,14], and a thermionic-vacuum arc [15].

To investigate the influences of dopant on the semiconductor behaviors, in our previous experiment, we reported Ge-doped GaN film deposited by a radio frequency (RF) reactive sputtering technique with a single ceramic target at the different Ge contents of the dopant of 0, 0.03, 0.07 and 1 . It was 
presented that all these Ge-doped GaN thin films acted in as an n-type semiconductor for the various Ge dopant ratios [16]. Besides, there were many previous works that studied the effects of different sputtering conditions on the doping GaN films $[5,17,18]$. However, there is not much research exploring the influence of the different growth conditions on Ge-doped GaN film made by the RF reactive sputtering technique until this work. In this research, we study the effects of RF sputtering conditions on properties of these $\mathrm{Ge}_{0.07} \mathrm{GaN}$ films. Firstly, $\mathrm{Ge}_{0.07} \mathrm{GaN}$ films were grown at different heating substrate temperatures from 100 to $400{ }^{\circ} \mathrm{C}$. Secondly, the RF sputtering power changed in the range of 90-150 W and was applied to prepare $\mathrm{Ge}_{0.07} \mathrm{GaN}$ films, while the deposition temperature was fixed at $300^{\circ} \mathrm{C}$.

\section{Experimental Details}

$\mathrm{Ge}_{0.07} \mathrm{GaN}$ thin films were successfully deposited on $\mathrm{Si}$ (100) substrate by radio-frequency (RF) reactive sputtering with a $\mathrm{Ge}_{0.07} \mathrm{GaN}$ single ceramic target containing 7 at the $\%$ of the $\mathrm{Ge} /(\mathrm{Ge}+\mathrm{Ga})$ molar ratio. To investigate the influences of deposition temperature, the substrates were heated in a range of $100-400{ }^{\circ} \mathrm{C}$ while the output RF power and sputtering time were kept at $120 \mathrm{~W}$ and $30 \mathrm{~min}$, respectively. To study the effects of different sputtering powers on properties of $\mathrm{Ge}_{0.07} \mathrm{GaN}$ films, the films were deposited under 90,120, and $150 \mathrm{~W}$ while the deposition temperature and duration of sputtering were held at $300{ }^{\circ} \mathrm{C}$ and $30 \mathrm{~min}$, respectively. The sputtering proceeded under the working pressure at $9 \times 10^{-3}$ torrs and the mixing gases of Argon flow rate at $5 \mathrm{sccm}$ and Nitrogen flow rate at $15 \mathrm{sccm}$. The size of the single cermet targets employed in RF sputtering was $5.08 \mathrm{~cm}$ (2 inches). The distance between the target and substrates in the working chamber for depositing was kept at $5 \mathrm{~cm}$, while the substrate faced the target. Details for preparing a single ceramic target and RF reactive sputtering process were presented in the previous experiment in our laboratory [16,18-21].

The structural crystallite of the sputtered $\mathrm{Ge}_{0.07} \mathrm{GaN}$ films deposited under the different heating substrates (range of $100-400^{\circ} \mathrm{C}$ ) was tested by X-ray diffractometry (XRD, D8 Discover, Bruker, Billerica, MA, USA). The morphological and topographical surfaces of these $\mathrm{Ge}_{0.07} \mathrm{GaN}$ films were investigated by scanning electron microscopy (SEM, JSM-6500F, JEOL, Tokyo, Japan) and atomic force microscopy (AFM, Dimension Icon, Bruker). The energy dispersive spectrometer (EDS, JSM-6500F, JEOL) prepared on SEM was employed to analyze the composition data of these films. A Hall measurement system (HMS-2000, Ecopia, Tokyo, Japan) including a maximum magnetic-field of 0.51T was applied for electrical properties. An Ultraviolet-Visible (UV-Vis) spectrometer (V-670, Jasco, Tokyo, Japan) was used to study the optical properties of $\mathrm{Ge}_{0.07} \mathrm{GaN}$ films.

\section{Results and Discussion}

\subsection{Effects of Growth Temperature on the Sputtered GeGaN Film Properties}

Compositional EDS investigation of the $\mathrm{Ge}_{0.07} \mathrm{GaN}$ films deposited in a temperature range from 100 to $400{ }^{\circ} \mathrm{C}$ is shown in Table 1. It is shown that the grown $\mathrm{Ge}_{0.07} \mathrm{GaN}$ films contained nitrogen from $48.4-49.7$ at. $\%$, and the $[\mathrm{N}] /([\mathrm{Ga}]+[\mathrm{Ge}])$ molar ratios were between $0.93-0.98$. It was illustrated that these $\mathrm{Ge}_{0.07} \mathrm{GaN}$ films were composed of slightly deficient nitrogen contents, and inadequate nitrogen was associated with the electrical properties of films. From EDS data displayed in Table 1, $[\mathrm{Ge}] /([\mathrm{Ge}]+[\mathrm{Ga}])$ molar ratios were $0.057,0.074,0.085$, and 0.094 for Ge-0.07-GaN films at heating substrate temperatures of $100,200,300$ and $400{ }^{\circ} \mathrm{C}$, respectively. As the heating substrate temperature increased, there was an increase in the Ge molar ratios of the sputtered $\mathrm{Ge}_{0.07} \mathrm{GaN}$ films. It was indicated that deposition temperature changed the Ge atom ratio in the deposited film to prove the effect of sputtering temperature on the film properties.

The morphological and topographical surface images of $\mathrm{Ge}_{0.07} \mathrm{GaN}$ films deposited at different deposition temperatures in the range from 100 to $400{ }^{\circ} \mathrm{C}$ are displayed in Figure 1. The SEM surface images indicated that the grown $\mathrm{Ge}_{0.07} \mathrm{GaN}$ films had a microstructure with continuous and smooth surfaces. From the cross-sectional SEM patterns in Figure 1, these $\mathrm{Ge}_{0.07} \mathrm{GaN}$ films had a 1.0-1.78 $\mu \mathrm{m}$ 
thickness and adhered well between $\mathrm{Ge}_{0.07} \mathrm{GaN}$ films and $\mathrm{Si}$ wafer with free cracks or voids at interfaces. From data seen in Table 2, as the growth temperature rose from 100 to $400{ }^{\circ} \mathrm{C}$, the growth rate corresponded to $33.33,39.0,43.33$, and $59.33 \mathrm{~nm} / \mathrm{min}$. The root-mean-square (rms) roughness values of these deposited $\mathrm{Ge}_{0.07} \mathrm{GaN}$ films were 1.35, 1.40, 3.0, $3.1 \mathrm{~nm}$ as the substrate temperatures in the sputtering process increased from 100 to $400{ }^{\circ} \mathrm{C}$. The sputtered GaN film made by RF sputtering technology had a roughness from 0.7 to $20 \mathrm{~nm}$ [22], while the roughness of the GaN films made by the MOCVD method was in the range of 0.5-3 nm [23]. As the deposition temperature changed from 100 to $400{ }^{\circ} \mathrm{C}, \mathrm{Ge}_{0.07} \mathrm{GaN}$ films deposited had an increase in roughness value from 1.35 to $3.1 \mathrm{~nm}$ and a smooth surface. The morphology of the $\mathrm{Ge}_{0.07} \mathrm{GaN}$ film became rougher as the heating temperature substrate increased. It could be determined that strong bombardment of argon against the $\mathrm{Ge}_{0.07} \mathrm{GaN}$ target at a higher RF sputtering temperature was responsible for the faster deposition rate and the higher roughness of the surface.

Table 1. EDS composition of $\mathrm{Ge}_{0.07} \mathrm{GaN}$ films under different deposition conditions.

\begin{tabular}{ccccccc}
\hline Sputtering Conditions & Ga (at. $\%)$ & Ge (at. $\%)$ & N (at. $\%)$ & \multicolumn{2}{c}{ [Ge]/([Ga]+[GeIN]/([Ga]+[Ge]) } \\
\hline Heating & 100 & 47.42 & 2.87 & 49.71 & 0.057 & 0.988 \\
Substrate $\left({ }^{\circ} \mathrm{C}\right)$ & 200 & 47.08 & 3.78 & 49.14 & 0.074 & 0.966 \\
& 300 & 46.83 & 4.35 & 48.82 & 0.085 & 0.954 \\
\hline RF Sputtering & 400 & 46.73 & 4.87 & 48.40 & 0.094 & 0.938 \\
Power $(W)$ & 120 & 49.39 & 3.89 & 46.72 & 0.073 & 0.877 \\
& 150 & 46.83 & 4.35 & 48.82 & 0.085 & 0.954 \\
\hline
\end{tabular}

Table 2. The influence of RF power and substrate temperature conditions on the structural properties.

\begin{tabular}{ccccc}
\hline \multicolumn{2}{c}{ Sputtering Conditions } & $\begin{array}{c}\text { Film Thickness } \\
(\boldsymbol{\mu \mathbf { m } )}\end{array}$ & $\begin{array}{c}\text { Deposition Rate } \\
(\mathbf{n m} / \text { minute) }\end{array}$ & Roughness (nm) \\
\hline \multirow{2}{*}{$\begin{array}{c}\text { Deposition } \\
\text { Temperature }\left({ }^{\circ} \mathrm{C}\right)\end{array}$} & 100 & 1.00 & 33.33 & 1.35 \\
& 200 & 1.17 & 39.00 & 1.40 \\
& 300 & 1.30 & 43.33 & 3.00 \\
Sputtering Power & 400 & 1.78 & 59.33 & 3.10 \\
$(\mathrm{~W})$ & 120 & 0.62 & 20.67 & 0.46 \\
& 150 & 1.30 & 43.33 & 3.00 \\
\hline
\end{tabular}

Figure 2a presented the XRD pattern and slow scan rate spectra of the $\mathrm{Ge}_{0.07} \mathrm{GaN}$ films grown by $\mathrm{RF}$ sputtering at a different heating temperature in the range of $100-400{ }^{\circ} \mathrm{C}$ and at $120 \mathrm{~W}$ of RF power under the mixing of $\mathrm{Ar} / \mathrm{N}_{2}$ input gases. From the surveyed XRD, all $\mathrm{Ge}_{0.07} \mathrm{GaN}$ films deposited on $\mathrm{Si}$ (100) substrates at temperature $100-400{ }^{\circ} \mathrm{C}$ were polycrystalline including structural wurtzite, and Ge constituted the solid-state solution in the GaN crystal structure [16]. It could be clearly seen that these $\mathrm{Ge}_{0.07} \mathrm{GaN}$ films with a preferential $(10 \overline{1} 0)$ growth plane had $(10 \overline{1} 0),(10 \overline{1} 1),(11 \overline{2} 0)$ and $(11 \overline{2} 2)$ peaks, and other secondary phases could not be found. At the higher heating temperature, the (1010) peak slightly shifted to the higher $2 \theta$ angle, and the $(10 \overline{10})$ peak of the deposited $\mathrm{Ge}_{0.07} \mathrm{GaN}$ films at 100, 200, 300 and $400^{\circ} \mathrm{C}$ was located at $32.25^{\circ}, 32.30^{\circ}, 32.36^{\circ}$ and $32.40^{\circ}$, respectively. Table 2 shows the parameters for the crystal structure of $\mathrm{Ge}_{0.07} \mathrm{GaN}$ films grown at different temperatures. The lattice constant $c$ slightly decreased from $5.21,5.20,5.18$ to $5.17 \AA$ and $a$ was $3.21,3.20,3.19$ and $3.18 \AA$, corresponding to GeGaN films made at the heating substrate temperatures of $100,200,300$ and $400^{\circ} \mathrm{C}$, respectively. Additionally, cell volumes of Ge-0.07-GaN films sputtered at 100, 200, 300, and $400^{\circ} \mathrm{C}$ were $46.57,46.13,45.70$ and 45.27 at $\AA^{3}$, respectively. From XRD data in Table 3, the dominant (1010) peaks of the $100-400{ }^{\circ} \mathrm{C}$ deposited $\mathrm{Ge}_{0.07} \mathrm{GaN}$ films were slightly reduced with respect to the full width at half maxima (FWHM) values, i.e., $0.34^{\circ}, 0.30^{\circ}, 0.27^{\circ}$ and $0.25^{\circ}$ at $100,200,300$, and $400{ }^{\circ} \mathrm{C}$, respectively. Additionally, the 
crystalline size could be computed by the Scherer equation and the was significantly greater at higher heating temperature: $24.33,27.57,30.64$, and $33.09 \mathrm{~nm}$ for the $\mathrm{Ge}_{0.07} \mathrm{GaN}$ films deposited at 100, 200, 300 , and $400{ }^{\circ} \mathrm{C}$, respectively. It could be believed that the heating temperature affected the structural crystallite of the film as the $\mathrm{Ge}_{0.07} \mathrm{GaN}$ films were deposited by RF sputtering at 100, 200, 300, and $400{ }^{\circ} \mathrm{C}$.

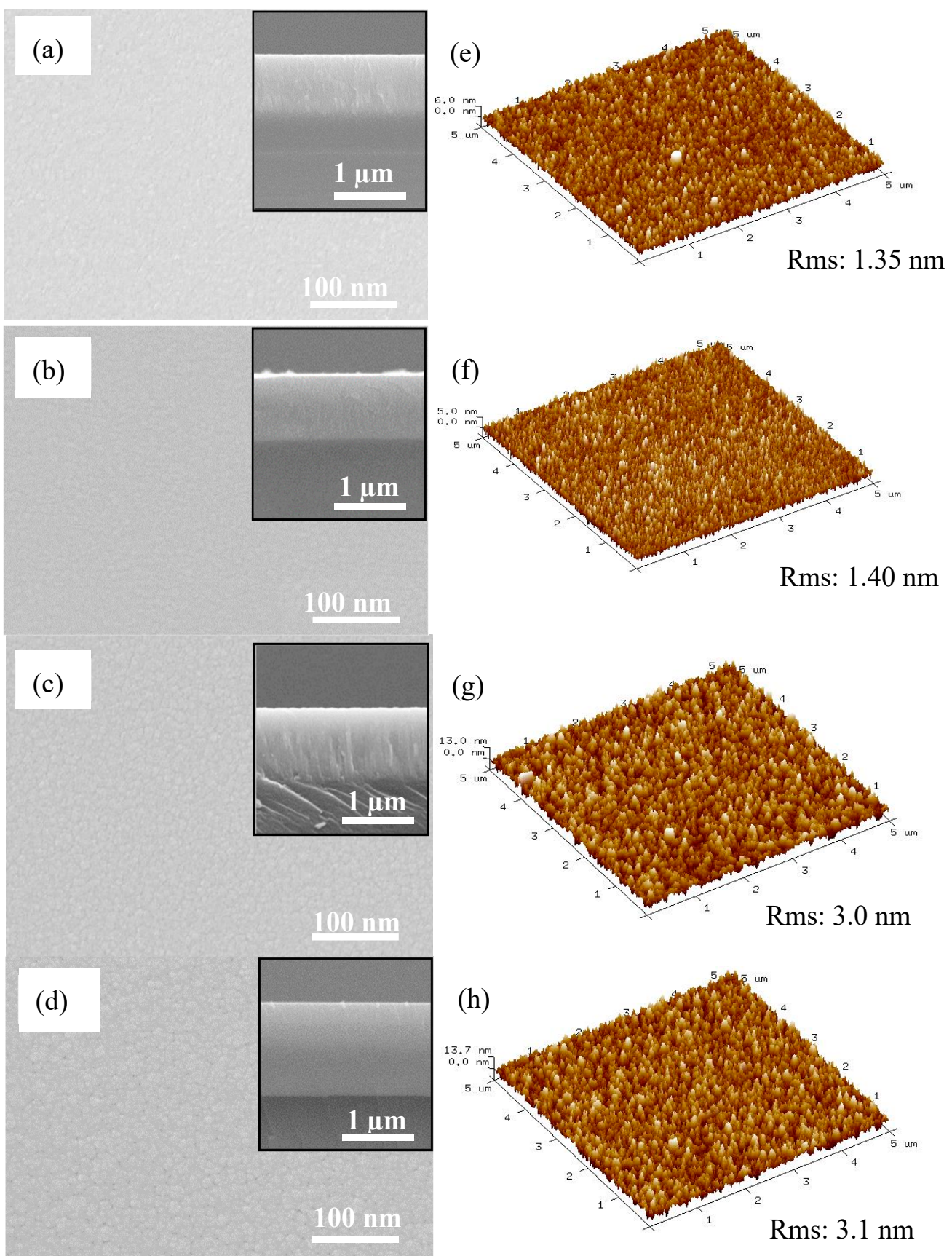

Figure 1. (a-d) SEM surface images and (e-h) $3 \mathrm{D}$ AFM morphologies of $\mathrm{Ge}_{0.07} \mathrm{GaN}$ films at $(\mathbf{a}, \mathbf{e}) 100^{\circ} \mathrm{C}$, $(\mathbf{b}, \mathbf{f}) 200{ }^{\circ} \mathrm{C},(\mathbf{c}, \mathbf{g}) 30$ and $400{ }^{\circ} \mathrm{C}$. The insets are their individual cross-sectional images. 

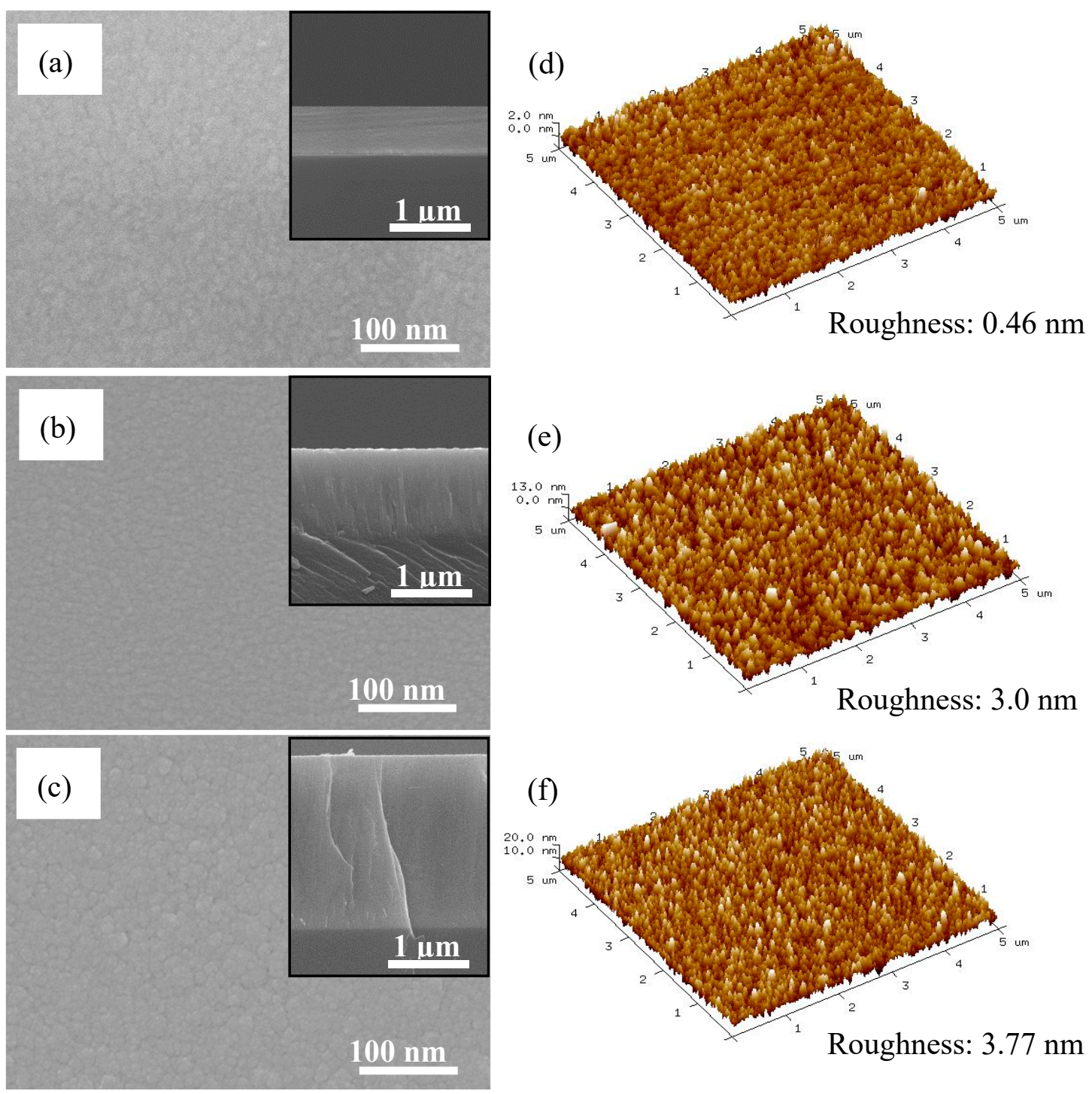

Figure 2. (a,b,d) SEM surface images and (e-g) 3D AFM morphologies of $\mathrm{Ge}_{0.07} \mathrm{GaN}$ films deposited at $(\mathbf{a}, \mathbf{d}) 90 \mathrm{~W},(\mathbf{b}, \mathbf{e}) 120 \mathrm{~W}$, and $(\mathbf{c}, \mathbf{f}) 150 \mathrm{~W}$ in $\mathrm{Ar} / \mathrm{N}_{2}$ atmosphere. The insets present their single cross-sectional images.

Table 3. Structure properties of $\mathrm{Ge}_{0.07} \mathrm{GaN}$ thin films at different sputtering powers and substrate temperature from $\mathrm{X}$-ray diffraction analyses.

\begin{tabular}{|c|c|c|c|c|c|c|c|}
\hline \multicolumn{2}{|c|}{ Sputtering Conditions } & \multirow{2}{*}{$\begin{array}{c}\left.\begin{array}{c}- \\
2 \theta(1010)\end{array}\right) \text { peak } \\
32.25\end{array}$} & \multirow{2}{*}{$\begin{array}{l}a(\AA) \\
3.21\end{array}$} & \multirow{2}{*}{$\frac{c(\AA)}{5.21}$} & \multirow{2}{*}{$\begin{array}{c}\begin{array}{c}\text { Volume } \\
\left(\AA^{3}\right)\end{array} \\
46.57\end{array}$} & \multirow{2}{*}{$\begin{array}{c}\text { FWHM (1010) } \\
\text { (degree) }\end{array}$} & \multirow{2}{*}{$\begin{array}{c}\text { Crystallite } \\
\text { Size (nm) }\end{array}$} \\
\hline \multirow{4}{*}{$\begin{array}{l}\text { Deposition } \\
\text { Temperature } \\
\quad\left({ }^{\circ} \mathrm{C}\right)\end{array}$} & 100 & & & & & & \\
\hline & 200 & 32.30 & 3.20 & 5.20 & 46.13 & 0.30 & 27.57 \\
\hline & 300 & 32.36 & 3.19 & 5.18 & 45.70 & 0.27 & 30.64 \\
\hline & 400 & 32.40 & 3.18 & 5.17 & 45.27 & 0.25 & 33.09 \\
\hline RF & 90 & 32.30 & 3.59 & 5.83 & 64.87 & 0.41 & 21.44 \\
\hline Sputtering & 120 & 32.36 & 3.38 & 5.49 & 54.26 & 0.27 & 33.04 \\
\hline Power (W) & 150 & 32.40 & 3.25 & 5.29 & 48.43 & 0.26 & 34.67 \\
\hline
\end{tabular}

The electrical properties of $\mathrm{Ge}_{0.07} \mathrm{GaN}$ films deposited at different temperatures in the range of $100-400{ }^{\circ} \mathrm{C}$ and the $120 \mathrm{~W}$ of RF power were investigated by the Hall measurement system. In previous experiments, we reported that the $300{ }^{\circ} \mathrm{C}$-sputtered $\mathrm{Ge}_{0.07} \mathrm{GaN}$ film achieved an electron concentration of $5.02 \times 10^{17} \mathrm{~cm}^{-3}$, mobility of $10.5 \mathrm{~cm}^{2} \cdot \mathrm{V}^{-1} \cdot \mathrm{s}^{-1}$, and carrier conductivity of $10.84 \mathrm{~S} \cdot \mathrm{cm}^{-1}$, and worked 
as an n-semiconductor layer [16]. From data displayed in Table 4 and Figure $3 a$, all sputtered $\mathrm{Ge}_{0.07} \mathrm{GaN}$ films at different growth temperatures from 100 to $400{ }^{\circ} \mathrm{C}$ remained $n$-type semiconductors. It could be explained that the compositional EDS data shown in Table 1 were responsible for the electrical properties of the $\mathrm{Ge}_{0.07} \mathrm{GaN}$ films. The $\mathrm{Ge}_{0.07} \mathrm{GaN}$ film at 100, 200, 300, and $400{ }^{\circ} \mathrm{C}$ had an increase in electron concentration $\left(\mathrm{n}_{\mathrm{e}}\right)$ from $1.64 \times 10^{16}, 2.14 \times 10^{17}, 5.02 \times 10^{17}$ to $1.30 \times 10^{18} \mathrm{~cm}^{-3}$, and a decrease in mobility $(\mu)$ between $33,17,11$ and $7 \mathrm{~cm}^{2} \cdot \mathrm{V}^{-1} \cdot \mathrm{s}^{-1}$, respectively. It is believed that electron concentration could be a function of electrical conductivity and the as-deposited GeGaN at 100, 200, 300 and $400{ }^{\circ} \mathrm{C}$ maintained the increase in electronic conductivity corresponding to $0.09,0.58,0.88$ and $1.46 \mathrm{~S} \cdot \mathrm{cm}^{-1}$, respectively. The practical electrical properties of these $\mathrm{Ge}_{0.07} \mathrm{GaN}$ films illustrated that there were effects of heating substrate temperatures on film properties.

Table 4. Electrical properties of $\mathrm{Ge}_{0.07} \mathrm{GaN}$ films deposited at different temperatures.

\begin{tabular}{|c|c|c|c|c|c|c|}
\hline \multicolumn{2}{|c|}{ Sputtering Conditions. } & \multirow{2}{*}{$\begin{array}{c}\text { Type } \\
\mathrm{n}\end{array}$} & \multirow{2}{*}{$\begin{array}{c}\begin{array}{c}\text { Concentration } \\
\mathbf{N}_{\mathrm{e}} \mathbf{~ c m}^{-3}\end{array} \\
1.64 \times 10^{16}\end{array}$} & \multirow{2}{*}{$\begin{array}{c}\begin{array}{c}\text { Mobility } \mu \\
\mathrm{cm}^{2} \cdot \mathrm{V}^{-\mathbf{1}} \cdot \mathbf{s}^{-1}\end{array} \\
33\end{array}$} & \multirow{2}{*}{$\begin{array}{c}\begin{array}{c}\text { Conductivity } \sigma \\
\mathbf{S} \cdot \mathbf{c m}^{-1}\end{array} \\
0.09\end{array}$} & \multirow{2}{*}{$\begin{array}{c}\begin{array}{c}\text { Bandgap } \\
\text { eV }\end{array} \\
3.14\end{array}$} \\
\hline & 100 & & & & & \\
\hline Deposition & 200 & $\mathrm{n}$ & $2.14 \times 10^{17}$ & 17 & 0.58 & 3.09 \\
\hline lemperature & 300 & $\mathrm{n}$ & $5.02 \times 10^{17}$ & 11 & 0.88 & 3.05 \\
\hline & 400 & $\mathrm{n}$ & $1.30 \times 10^{18}$ & 7 & 1.46 & 3.02 \\
\hline \multirow{3}{*}{$\begin{array}{l}\text { Sputtering } \\
\text { Power (W) }\end{array}$} & 90 & $\mathrm{n}$ & $3.22 \times 10^{15}$ & 25 & 0.012 & 3.14 \\
\hline & 120 & $\mathrm{n}$ & $5.02 \times 10^{17}$ & 11 & 0.84 & 3.05 \\
\hline & 150 & $\mathrm{n}$ & $5.50 \times 10^{19}$ & 4 & 35.2 & 2.96 \\
\hline
\end{tabular}
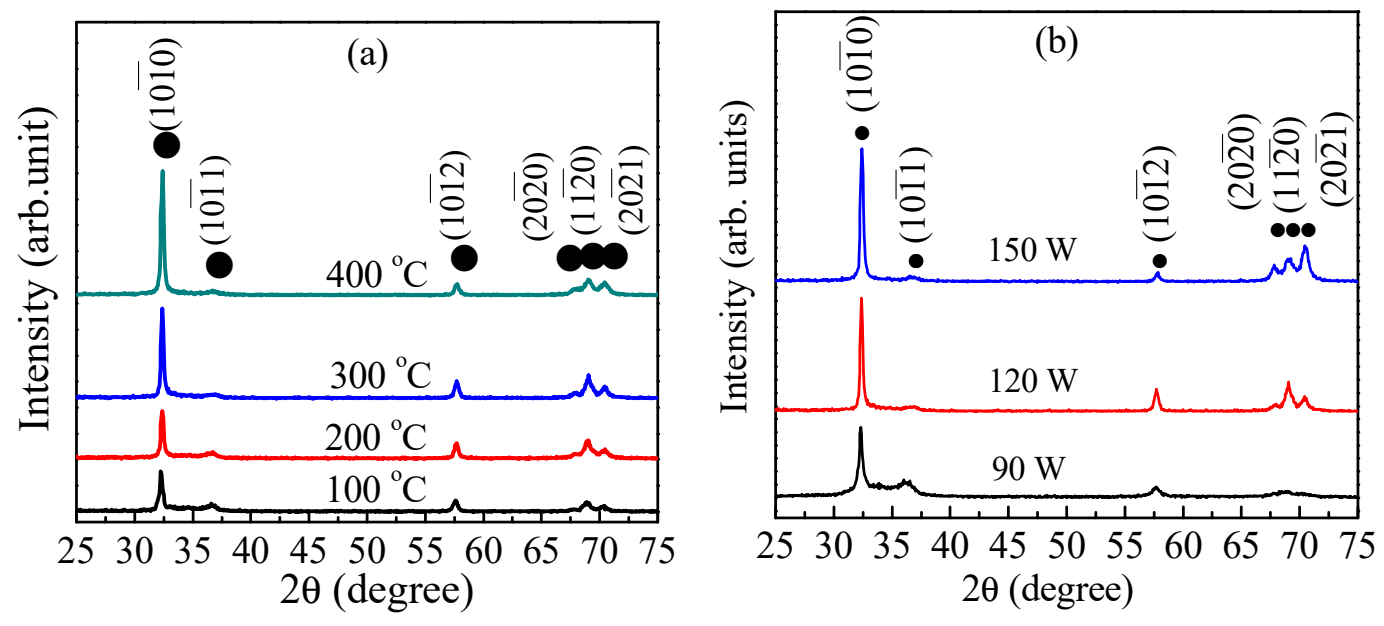

Figure 3. $\mathrm{XRD}$ patterns of $\mathrm{Ge}_{0.07} \mathrm{GaN}$ films deposited at (a) different growth temperatures; (b) different RF power (90-150 W) in an $\mathrm{Ar} / \mathrm{N}_{2}$ atmosphere.

The absorption of GeGaN films was studied by UV-Vis measurement at room temperature. The Equation (1) named the Tauc equation has been used to show the optical absorption coefficient and energy bandgap $\left(E_{\mathrm{g}}\right)$ of $\mathrm{Ge}_{0.07} \mathrm{GaN}$ films from the UV-Vis database.

$$
(\alpha h v)^{2}=A\left(h v-E_{\mathrm{g}}\right)
$$

where $A$ is a invariable number, $\alpha$ is the coefficient of optical absorption. From equation, the incident photon and the $\mathrm{Ge}_{0.07} \mathrm{GaN}$ films bandgap of energies were determined and listed for $h v$ and $E_{\mathrm{g}}$. Figure $4 \mathrm{a}$ and Table 4 show the plots of the $(\alpha h v)^{2}-h v$ curves and the bandgap values of $\mathrm{Ge}_{0.07} \mathrm{GaN}$ films deposited at different temperatures, which could be directly obtained by extrapolating the linear part of these curves. The $E_{\mathrm{g}}$ values from the extrapolated curves were 3.14, 3.09, 3.05, and $3.02 \mathrm{eV}$ for $\mathrm{Ge}_{0.07} \mathrm{GaN}$ films deposited at different temperatures from 100 to $400{ }^{\circ} \mathrm{C}$. 

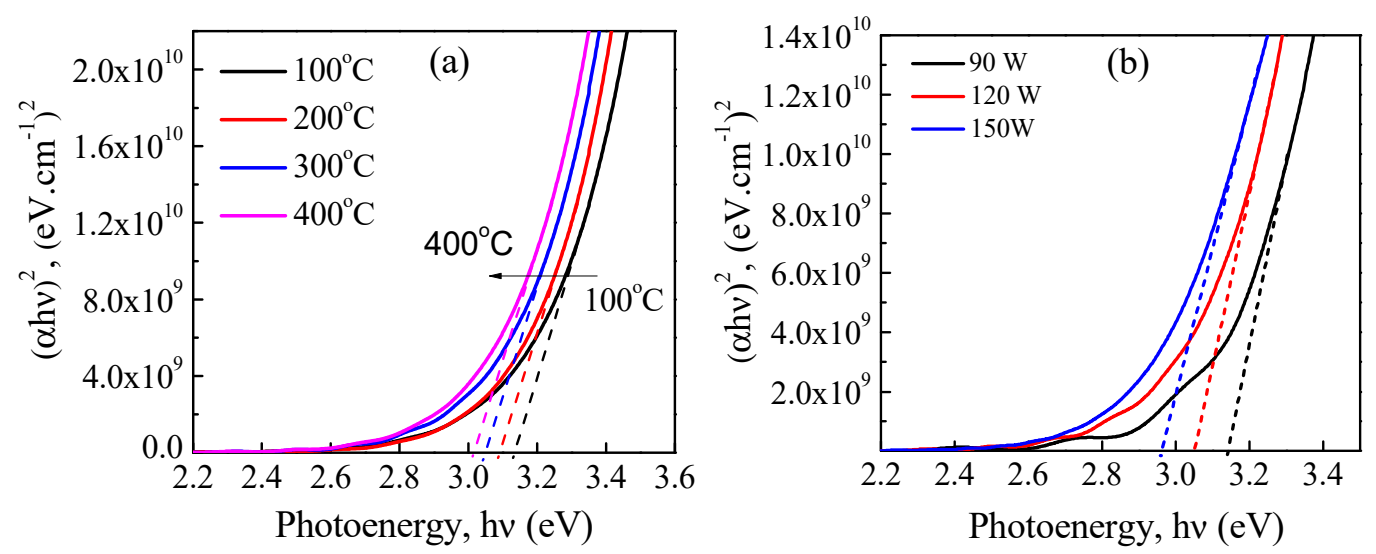

Figure 4. Plots of $(\alpha h v)^{2}$ vs. photon energy $(h v)$ for the optical band gap determination of the $\mathrm{Ge}_{0.07} \mathrm{GaN}$ films sputtered in a (a) deposition temperature $\left(100-400{ }^{\circ} \mathrm{C}\right)$ range; (b) RF reactive sputtering range of 90-150 W.

\subsection{Influences of RF Sputtering Power on the Electrical, Optical and Structural Properties of Ge-Doped Gan Thin Films}

The composition of $\mathrm{Ge}_{0.07} \mathrm{GaN}$ films as-deposited at 90, 120 and $150 \mathrm{~W}$ RF sputtering power is shown in Table 1. The ratios of molar $[\mathrm{Ge}] /([\mathrm{Ge}]+[\mathrm{Ga}])$ were $7.3,8.5$ and 9.9 at $\%$ for $\mathrm{Ge}_{0.07} \mathrm{GaN}$ films grown at 90, 120 and $150 \mathrm{~W}$, respectively. Under output RF power conditions, the Ge content in sputtered films increased with the RF power. Moreover, the nitrogen contents in these films were less than 50 at \%, which indicates that there was a nitrogen-deficiency state in $\mathrm{Ge}_{0.07} \mathrm{GaN}$ films at different sputtering powers.

The surface morphology and cross-section images of Ge-GaN films grown at different output RF sputtering powers are presented in Figure 4. The results of SEM images showed the smoothness surface and grains in nanometer size without voids and mechanical fracture phenomena. It is found that the higher sputtering power of deposition processes is the reason for the crystal grains having sufficient energy, causing the increase in the size of grains. From the cross-sectional patterns of $\mathrm{Ge}_{0.07} \mathrm{GaN}$ films at 90-150 W of RF power in Figure 5, film thickness increased from 0.62 to $2.5 \mu \mathrm{m}$ and explained the excellent adhesion, and no cracks or holes appeared at the surface between Si substrate and films. It can be observed that the thickness of the film increased as the film was deposited under a higher sputtering power. This means that the sputtering rate increased because the number of atoms deposited on the substrate increase and the film thickness will become thicker. From data in Table 3, the sputtering growth rate was 20.6743 .33 and $83.33 \mathrm{~nm} /$ min corresponding to 90,120 and $150 \mathrm{~W}$ of deposition power. This experiment successful prepared $\mathrm{Ge}_{0.07} \mathrm{GaN}$ films under different sputtering powers without a buffer layer film. It can be seen from Figure 2 that GeGaN films have increased grain size as the RF sputtering power increased from 90 to $150 \mathrm{~W}$, which is due to the higher the sputtering power, the higher the current density of the plasma, and the free energy of the gas molecules, which increases, so that the opportunity to effectively hit the target increased, while the sputtered atoms have a large kinetic energy, arrived at the substrate with a high surface energy for grain growth, and increased the grain size. Using the Scherer equation, the crystalline size could be 24.33, 27.57, 30.64, and $33.09 \mathrm{~nm}$ for the $\mathrm{Ge}_{0.07} \mathrm{GaN}$ films grown at 90, 120, and $150 \mathrm{~W}$, respectively. 

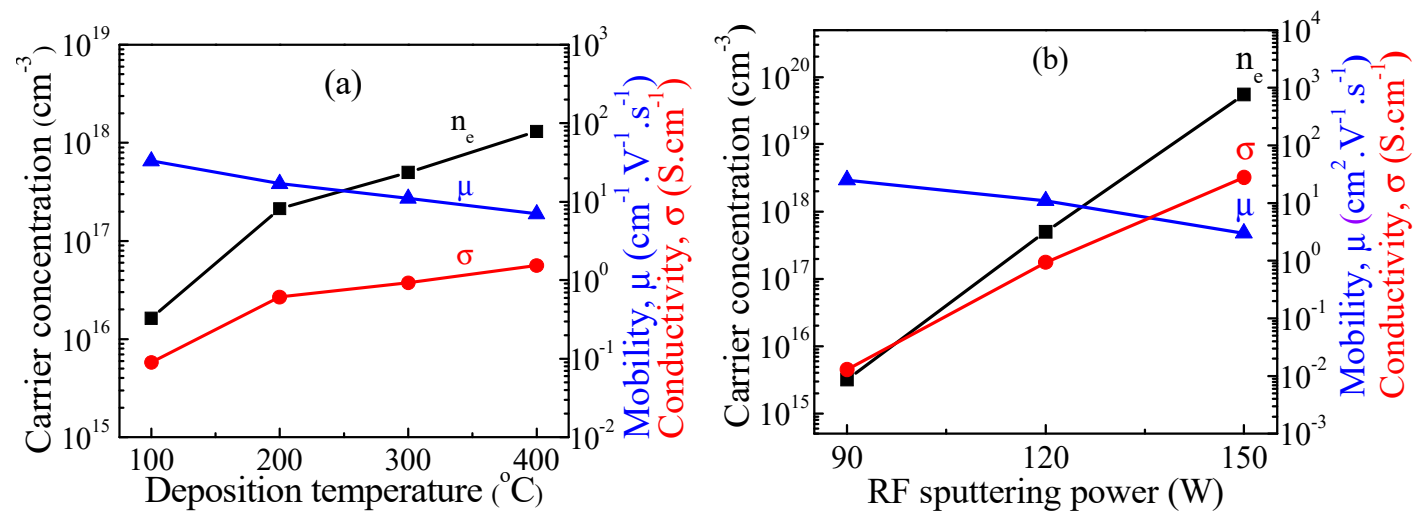

Figure 5. Electrical properties of $\mathrm{Ge}_{0.07} \mathrm{GaN}$ films deposited under a (a) heating substrate temperature range of $100-400{ }^{\circ} \mathrm{C}$, (b) RF sputtering power from 90 to $150 \mathrm{~W}$.

Under deposition power conditions of 90, 120 and $150 \mathrm{~W}$, the roughness of Ge-doped GaN films was $0.46,3.0$ and $3.2 \mathrm{~nm}$, respectively. It is explained that there is a relationship between the increase in sputtering power and the surface roughness of the film. The result of the roughness of films showed that higher bombardment of atoms from the target resulted in an increase in the deposition rate at higher sputtering power. Under higher output power, atoms have high surface movement energy to cause coarsening of grains and increases in the surface roughness of films.

Figure $3 \mathrm{~b}$ shows the $\mathrm{XRD}$ images of $\mathrm{Ge}_{0.07} \mathrm{GaN}$ thin films deposited under different output powers of 90,120 and $150 \mathrm{~W}$. The XRD results show that these $\mathrm{Ge}_{0.07} \mathrm{GaN}$ films exhibited a wurtzite structure. At the higher RF power of 120 and $150 \mathrm{~W}$, the sputtered $\mathrm{Ge}_{0.07} \mathrm{GaN}$ films were polycrystalline. However, there was deficient momentum between atoms and the substrate during the depositing process at $90 \mathrm{~W}$ RF power with respect to the low-quality crystallite of the $\mathrm{Ge}_{0.07} \mathrm{GaN}$ film. The $(10 \overline{1} 0),(10 \overline{1} 1),(10 \overline{1} 2)$, $(11 \overline{2} 0)$ and $(11 \overline{2} 2)$ diffraction peaks were found in Ge-GaN films, and no other secondary phase was detected. The peak positions of the $(10 \overline{1} 0)$ lattice plane were located at $32.30^{\circ}, 32.36^{\circ}$ and $32.40^{\circ}$ as the sputtering power was kept at 90, 120, and $150 \mathrm{~W}$, respectively. The $2 \theta$ angle of diffraction peaks slightly shifted higher at higher power. Table 2 shows all the calculated data from the XRD investigation. The a, c lattice constants and a unit cell volume of Ge-GaN films slightly degraded at higher RF power. While the c lattice constant slightly dropped from $5.83 \AA, 5.49 \AA$, and to $5.29 \AA$, there was a reduction in the a lattice constant from $3.59 \AA, 3.38 \AA$, and to $3.25 \AA$, with the cell volume of $64.87 \AA^{3}, 54.26 \AA^{3}$ to 48.43 $\AA^{3}$ corresponding to 90,120 and $150 \mathrm{~W}$, respectively. The full-width-half-maximum (FWHM) values of the $(10 \overline{10})$ diffraction peaks of the $2 \theta$ value decreased from $0.41^{\circ}$ for $90 \mathrm{~W}$ power to $0.26^{\circ}$ for $150 \mathrm{~W}$ power. From XRD investigation at the higher sputtering power, the $\mathrm{Ge}_{0.07} \mathrm{GaN}$ films achieved a higher crystallinity quality. The XRD of $\mathrm{Ge}_{0.07} \mathrm{GaN}$ film deposited at $90 \mathrm{~W}$ showed the worst crystallinity because the low sputtering power condition created less Ge in the film. All the evidence indicates the formation of GeGaN films was affected by different sputtering powers.

Electrical properties of $\mathrm{Ge}_{0.07} \mathrm{GaN}$ films sputtered under output powers of 90, 120, and $150 \mathrm{~W}$ were investigated by the Hall effect measurement system at room temperature. The electron concentration $\left(n_{\mathrm{e}}\right)$, mobility $(\mu)$, and conductivity $(\sigma)$ are plotted in Figure $4 \mathrm{~b}$ and shown in Table 4 . All the $\mathrm{Ge}_{0.07} \mathrm{GaN}$ films deposited under different output powers presented as a semiconductor of the n-type. The electrical concentration $\left(n_{\mathrm{e}}\right)$ was $3.22 \times 10^{15}, 5.02 \times 10^{17}$ and $5.50 \times 10^{19} \mathrm{~cm}^{-3}$ while the electron mobility ( $\mu$ ) was 25,11 and $4 \mathrm{~cm}^{2} \cdot \mathrm{V}^{-1} \cdot \mathrm{s}^{-1}$ at the sputtering power of 90,120 , and $150 \mathrm{~W}$, respectively. The results from the experiments showed that carrier concentration increased with sputtering power. It can be explained that the sputtering power provides energy to the Ge solid solution in the GaN lattice. At low sputtering power, insufficient Ge solid solution precipitated at the grain boundaries prevents internal carrier transfer in films, which causes a lower free carrier concentration while Ge solid solution can be increased with the power upgrade. Additionally, the electrical conductivity $(\sigma)$ of the films was 
affected by carrier concentration $\left(n_{\mathrm{e}}\right)$ and mobility $(\mu)$, and electrical conductivity $(\sigma)$ was $0.012,0.84$ and $35.2 \mathrm{~S} \cdot \mathrm{cm}^{-1}$. The data show that the electrical conductivity increases as the output power increases.

The absorption coefficient and optical bandgap $\left(E_{\mathrm{g}}\right)$ of $\mathrm{Ge}_{0.07} \mathrm{GaN}$ films deposited at room temperature on a transparent glass plate at $90-150 \mathrm{~W}$ were tested by UV-Vis spectrometry. Figure $5 \mathrm{~b}$ shows the extrapolated linear part of the $(\alpha h v)^{2}-h v$ curves from which the optical bandgap of $\mathrm{Ge}_{0.07} \mathrm{GaN}$ films could be directly achieved, and the energy bandgap $E_{\mathrm{g}}$ was $3.14,3.05,2.96 \mathrm{eV}$ for $\mathrm{Ge}_{0.07} \mathrm{GaN}$ films under power conditions of 90,120 and $150 \mathrm{~W}$, respectively. As the sputtering power increased, the energy gap gradually became smaller and decreased by $0.18 \mathrm{eV}$ from 90 watts to 150 watts. It is concluded that the increase in the RF power supplied sufficient energy to dissolve the Ge atoms into the lattice of $\mathrm{GaN}$, resulting in a decrease in the energy gap. As a result of electrical properties, it can be found that the carrier concentration increased with the increase in the sputtering power, and the film deposited at 150 watts has the highest carrier concentration and teh minimum energy gap.

\section{Conclusions}

$\mathrm{Ge}_{0.07} \mathrm{GaN}$ films were deposited on $\mathrm{Si}(100)$ substrates by employing radio frequency reactive magnetron sputtering technology at different temperature and RF power conditions. The characteristics and microstructure of these GeGaN films were studied thoroughly by AFM, SEM, XRD, UV-Vis spectrometry and the Hall effect measurement. The results showed that the $\mathrm{Ge}_{0.07} \mathrm{GaN}$ films remained in the polycrystalline structure and conductivity under the different growth conditions. The various sputtering conditions of the deposition process affected structural GeGaN films and resulted in heavy structural distortion. Compared with the sputtered film at different RF power values in the range of 90-150 W, the sputtered-150 W Ge $e_{0.07} \mathrm{GaN}$ films achieved the lowest energy bandgap of $2.96 \mathrm{eV}$, the highest carrier concentration of $5.50 \times 10^{19} \mathrm{~cm}^{-3}$ and electrical conductivity of $35.2 \mathrm{~S} \cdot \mathrm{cm}^{-1}$, and $4 \mathrm{~cm}^{2} \cdot \mathrm{V}^{-1} \cdot \mathrm{s}^{-1}$ mobility. Besides, the analysis of $\mathrm{Ge}_{0.07} \mathrm{GaN}$ films at different substrate temperatures proved the influences of deposition temperature on the structure and properties of the films. From all investigated data, it could be believed that growth conditions of the RF reactive sputtering process affected the structure and properties of $\mathrm{Ge}_{0.07} \mathrm{GaN}$ films.

Author Contributions: Data curation, C.P.T. and T.T.A.T.; Methodology; Writing-original draft, investigation, C.P.T. and T.T.A.T., Formal analysis, Funding acquisition, Writing-review \& editing, C.P.T., T.T.A.T., N.H.V., K.A.T., T.T.V.S.N., K.V.N., and N.V.S.; Supervision, D.-H.K.

Funding: This research was funded by the Ministry of Science and Technology of the Republic of China under grant number 107-2221-E-011-141-MY3.

Conflicts of Interest: The authors declare no conflict of interest.

\section{References}

1. Akasaki, I.; Amano, H. Crystal growth and conductivity control of group III nitride semiconductors and their application to short wavelength light emitters. Jpn. J. Appl. Phys. 1997, 36, 5393-5408. [CrossRef]

2. Fujii, T.; Gao, Y.; Sharma, R.; Hu, E.L.; DenBaars, S.P.; Nakamura, S. Increase in the extraction efficiency of GaN-based light-emitting diodes via surface roughening. Appl. Phys. Lett. 2004, 84, 855-857. [CrossRef]

3. Pearton, S.J.; Ren, F.; Zhang, A.P.; Lee, K.P. Fabrication and performance of GaN electronic devices. Mater. Sci. Eng. R Rep. 2000, 30, 205-212. [CrossRef]

4. Tuan, T.T.A.; Kuo, D.-H. Characteristics of RF reactive sputter-deposited $\mathrm{Pt} / \mathrm{SiO}_{2} / \mathrm{n}$-InGaN MoS Schottky diodes. Mater. Sci. Semicond. Process. 2015, 30, 314-320. [CrossRef]

5. Tuan, T.T.A.; Kuo, D.-H.; Saragih, A.D.; Li, G.-Z. Electrical properties of RF-sputtered Zn-doped GaN films and $\mathrm{p}-\mathrm{Zn}-\mathrm{GaN} / \mathrm{n}-\mathrm{Si}$ hetero junction diode with low leakage current of $10^{-9} \mathrm{~A}$ and a high rectification ratio above $10^{5}$. Mater. Sci. Eng. B. 2017, 222, 18-25. [CrossRef]

6. Kuo, D.-H.; Liu, Y.-T. Characterization of quaternary $\mathrm{Zn} / \mathrm{Sn}$-codoped GaN films obtained with $\mathrm{Zn}_{x} \mathrm{Sn}_{0.04} \mathrm{GaN}$ targets at different $\mathrm{Zn}$ contents by the RF reactive magnetron sputtering technology. J. Mater. Sci. 2018, 53, 9099-9106. [CrossRef] 
7. Nakamura, S.; Mukai, T.; Senoh, M. Si- and Ge-doped GaN films grown with GaN buffer layers. Jpn. J. Appl. Phys. 1992, 31, 2883-2888. [CrossRef]

8. Hageman, P.R.; Schaff, W.J.; Janinski, J.; Liliental-Weber, Z. n-type doping of wurtzite GaN with germanium grown with plasma-assisted molecular beam epitaxy. J. Cryst. Growth. 2004, 267, 123-128. [CrossRef]

9. Colussi, M.L.; Baierle, R.J.; Miwa, R.H. Doping effects of C, Si and Ge in wurtzite [0001] GaN, AlN, and InN nanowires. J. Appl. Phys. 2011, 110, 033709. [CrossRef]

10. Oshima, Y.; Yoshida, T.; Watanabe, K.; Mishima, T. Properties of Ge-doped, high-quality bulk GaN crystals fabricated by hydride vapor phase epitaxy. J. Cryst. Growth. 2010, 312, 3569-3573. [CrossRef]

11. Kirste, R.; Hoffmann, M.P.; Sachet, E.; Bobea, M.; Bryan, Z.; Bryan, I.; Nenstiel, C.; Hoffmann, A.; Maria, J.-P.; Collazo, R.; et al. Ge doped GaN with controllable high carrier concentration for plasmonic applications. Appl. Phys. Lett. 2013, 103, 242107. [CrossRef]

12. Shikanaia, A.; Fukahori, H.; Kawakami, Y.; Hazu, K.; Sota, T.; Mitani, T.; Mukai, T.; Fujita, S. Optical properties of Si-, Ge- and Sn-doped GaN. Phys. Status. Solidi. B 2003, 235, 26-30. [CrossRef]

13. Dadgar, A.; Bläsing, J.; Diez, A.; Krost, A. Crack-free, highly conducting GaN layers on Si substrates by Ge doping. Appl. Phys. Express. 2011, 4, 011001. [CrossRef]

14. Fritze, S.; Dadgar, A.; Witte, H.; Bügler, M.; Rohrbeck, A.; Bläsing, J.; Hoffmann, A.; Krost, A. High Si and Ge n-type doping of GaN doping-Limits and impact on stress. Appl. Phys. Lett. 2012, 100, 122104. [CrossRef]

15. Özen, S.; Korkmaz, S..; Şenay, V.; Pat, S. The substrate effect on Ge doped GaN thin films coated by thermionic vacuum arc. J. Mater. Sci.: Mater. Electron. 2017, 28, 1288-1293. [CrossRef]

16. Thao, C.P.; Kuo, D.H. Electrical and structural characteristics of Ge-doped GaN thin films and its hetero-junction diode made all by RF reactive sputtering. Mater. Sci. Semicond Process 2018, 74, 336-341. [CrossRef]

17. Li, C.-C.; Kuo, D.-H. Effects of growth temperature on electrical and structural properties of sputtered GaN films with a cermet target. J. Mater. Sci.: Mater. Electron. 2014, 25, 1404-1409. [CrossRef]

18. Thao, C.P.; Kuo, D.-H.; Jan, D.-J. Codoping effects of the Zn acceptor on the structural characteristics and electrical properties of the Ge donor-doped GaN thin films and its hetero-junction diodes all made by reactive sputtering. Mater. Sci. Semicond. Process. 2018, 82, 126-134. [CrossRef]

19. Li, C.-C.; Kuo, D.-H. Material and technology developments of the totally sputtering-made p/n GaN diodes for cost-effective power electronics. J. Mater. Sci.: Mater. Electron. 2014, 25, 1942-1948. [CrossRef]

20. Tuan, T.T.A.; Kuo, D.-H.; Li, C.C.; Yen, W.-C. Schottky barrier characteristics of Pt contacts to all sputtering-made n-type GaN and MoS diodes. J. Mater. Sci.: Mater. Electron. 2014, 25, 3264-3270. [CrossRef]

21. Ting, C.-W.; Thao, C.P.; Kuo, D.-H. Electrical and structural characteristics of tin-doped GaN thin films and its hetero-junction diode made all by RF reactive sputtering. Mater. Sci. Semicond Process. 2017, 59, 50-55. [CrossRef]

22. Kim, H.W.; Kim, N.H. Preparation of GaN films on Zno buffer layers by rf magnetron sputtering. Appl. Surf. Sci. 2004, 236, 192-197. [CrossRef]

23. Chyr, I.; Lee, B.; Chao, L.C.; Steckl, A.J. Damage generation and removal in the $\mathrm{Ga}^{+}$focused ion beam micromachining of GaN for photonic applications. J. Vac. Sci. Technol. 1999, 17, 3063-3067. [CrossRef]

(C) 2019 by the authors. Licensee MDPI, Basel, Switzerland. This article is an open access article distributed under the terms and conditions of the Creative Commons Attribution (CC BY) license (http://creativecommons.org/licenses/by/4.0/). 